\title{
Our approach to cases with fungus balls of the paranasal sinuses
}

\author{
Paranazal sinüs mantar topu olgularına yaklaşımımız \\ Alper Nabi Erkan, Alper Köycü \\ Department of Otolaryngology, Faculty of Medicine, Başkent University, Ankara, Turkey
}

\begin{abstract}
Objective: To retrospectively evaluate clinical and radiological characteristics of the patients with paranasal sinus fungus ball.

Methods: The medical files of nine patients who had been operated between April 2010 and November 2013 in Adana Hospital of the Başkent University with the diagnosis of fungus balls of paranasal sinuses were analyzed. Patients with fungus infection which was showed tissue invasion, allergic mucin, rich of eosinophil and granulomatous tissue in histopathologic examination were excluded in the study. Demographic characteristics, physical examination findings, results of computed tomography, culture and histopathologic examinations were analyzed.

Results: Study population consisted of three men and six women with a mean age of 64.5 (range: 35 to 78 ) years. In all patients, an intrasinusal hyperdense heterogenous image was detected on paranasal sinus tomograms. Fungus balls were noted in the right maxillary sinus in five $(77.7 \%)$ and in sphenoid sinus in two $(22.3 \%)$ patients. Only three (33.3\%) patients had not any other systemic disease. All patients underwent functional endoscopic sinus surgery. On histopathological examination, results of all patients were reported as fungus balls.

Conclusion: In cases presenting with a systemic disease associated with non-specific symptoms of sinusitis, the presence of a fungus ball should be considered.
\end{abstract}

Keywords: Sinusitis, fungal sinusitis, fungus ball.

\section{Özet}

Amaç: Bu çalışmada paranazal sinüs mantar topu nedeni ile opere edilen olgularımızın klinik ve radyolojik verilerinin retrospektif olarak değerlendirilmesini amaçladık.

Yöntem: Başkent Üniversitesi Adana Hastanesi'nde Nisan 2010 ile Kasım 2013 tarihleri arasında paranazal sinüs mantar topu teşhisi ile opere edilen dokuz hastanın kayıtları incelendi. Patolojik incelemede doku invazyonu gösteren, eozinofilden zengin, alerjik müsin ve granülomatöz yapılar bulunduran mantar enfeksiyonu olan hastalar çalışma dışında bırakıldı. Olguların demografik özellikleri, fizik muayene bulguları, bilgisayarlı tomografi, histopatolojik inceleme ve kültür sonuçları değerlendirildi.

Bulgular: Olguların üç tanesi erkek, altı tanesi kadındı ve yaş ortalaması 64.5 (dağılım: 35-78) idi. Tüm hastalarda, paranazal sinüs tomografi sonucunda, sinüs içerisinde hiperdens heterojen görünüm saptand. Yedi (\%77.7) hastada maksiler sinüste, iki (\%22.3) hastada ise sfenoid sinüste mantar topu tespit edildi. Sistemik hiçbir hastalı̆̆ olmayan sadece üç (\%33.3) hasta mevcut idi. Tüm hastalara fonksiyonel endoskopik sinüs cerrahisi uyguland. Hastaların histopatolojik inceleme sonuçları mantar topu ile uyumlu bulundu.

Sonuç: Nonspesifik sinüzit bulguları ile başvuran ve eşlik eden sistemik hastalığı olan olgularda, paranazal sinus mantar topunun ayırıcı tanıda akılda tutulması gereklidir.

Anahtar sözcükler: Sinüzit, mantar sinüziti, mantar topu.
Fungi are one of the etiological agents of rhinosinusitis. Although incidence of fungal rhinosinusitis changes, it has been reported as ranging between 13.5 and 28 percent. ${ }^{[1,2]}$ Cases with fungal rhinosinusitis are classified into two categories according to the presence of hyphas as invasive or non-invasive (extramucosal). ${ }^{[3,4]}$ Non-invasive fungal rhinosinusitis is divided in 4 subgroups, as superficial sinonasal colonisation (saprophytic), fungus ball, allergic fungal sinusitis and eosinophilic fungal rhinosinusitis, while cases with invasive fungal sinusitis are analyzed in 3 groups as acute ful-

\footnotetext{
Correspondence: Alper Nabi Erkan, MD. Başkent Üniversitesi, Adana Seyhan Hastanesi KBB Bölümü, Baraj Yolu 1. Durak 01230 Seyhan, Adana, Turkey.

e-mail: alpernabierkan@yahoo.com
}

Received: February 28, 2014; Accepted: March 7, 2014; Published online: May 5, 2014
Online available at: www.jmedupdates.org doi: $10.2399 / \mathrm{jmu} .2014001006$ QR code: 
minant, chronic invasive and granulomatous invasive fungal sinusitis. Fungus balls are usually seen in individuals with normally functioning immune system. However, in conditions where immune system weakens, they can become potentially life-threatening invasive fungal infections. ${ }^{[5]}$

The aim of the present study was to retrospectively evaluate clinical and imaging characteristics of the patients with paranasal sinus fungus ball.

\section{Materials and Methods}

In this study, the medical files of 9 patients who had been operated between April 2010 and November 2013 in the Adana Hospital of the Baskent University with the diagnosis of fungus balls were retrospectively analyzed. Age, gender of the patients, affected sinus, presence of a systemic disease, results of culture and histopathological analysis were recorded. Presenting complaints and physical examination findings were analyzed. Preoperatively diagnostic paranasal sinus tomograms were obtained from all patients. All patients underwent endoscopic sinus surgery. Surgical specimens were sent to the laboratory for culture and histopathological examination. Patients with fungal infection whose histopathological examination revealed allergic mucinous and granulomatous formations rich in eosinophils, which invaded surrounding tissues, were excluded from the study.

\section{Results}

Nine patients who had undergone surgical treatment with detected fungus balls were included in the study. Study population consisted of three men and six women with a mean age of 64.5 (range: 35 to 78) years. Major complaints of the patients were nasal discharge, maxillary pain and coughing. Nasal discharge was the most frequently seen physical examination finding. In all patients, an intrasinusal hyperdense heterogenous image was detected on paranasal sinus tomograms (Fig. 1). Fungus balls were noted in the maxillary sinus in seven (77.7\%) (Fig. 2) and sphenoid sinus in two $(22.3 \%)$ patients. In one patient hepatitis B infection and in eight patients more than one systemic disease (diabetes mellitus, $\mathrm{n}=3$; hypertension, $\mathrm{n}=3$; chronic renal failure, $\mathrm{n}=2$ : asthma and allergy, $n=1$; tuberculosis, $n=1$ ) were detected. Only three $(33.3 \%)$ patients had not any other systemic disease. All patients underwent functional endoscopic sinus surgery (FESC). During surgery, a wide antrostomy incision was made and inner side of the sinus was completely cleared of fungal material and irrigated with pressurized physiological saline. Any complication did not develop. During surgery, any additional surgical method was not required and no incident of recurrence was observed during follow-ups.

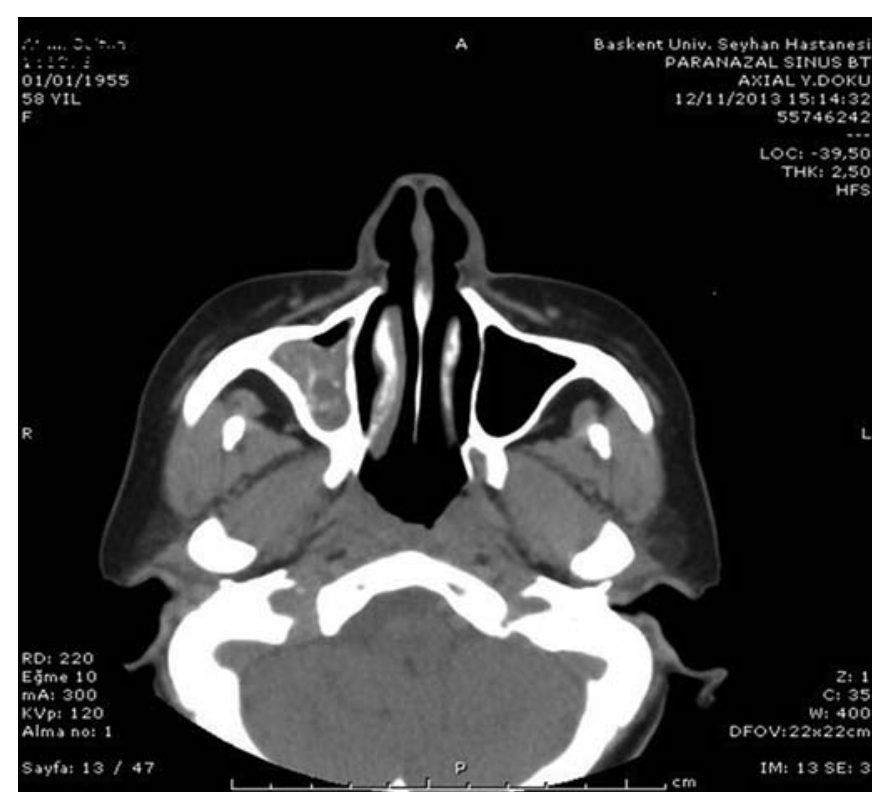

Fig. 1. Fungus ball in the right maxillary sinus as detected on axial section of paranasal sinus CT (Case \#7).

On histopathological examination, results of all patients were reported as fungus balls. In any of the specimens, eosinophilic infiltration, allergic mucin, granuloma or tissue invasion were not observed. Specimens of 6 out of 9 patients were sent for fungal culture and fungal growth (Aspergillus fumigatus, $\mathrm{n}=2$ and Dematiaceous sp., $\mathrm{n}=1$ ) was detected in only 3 specimens. The findings of all patients are summarized in Table 1.

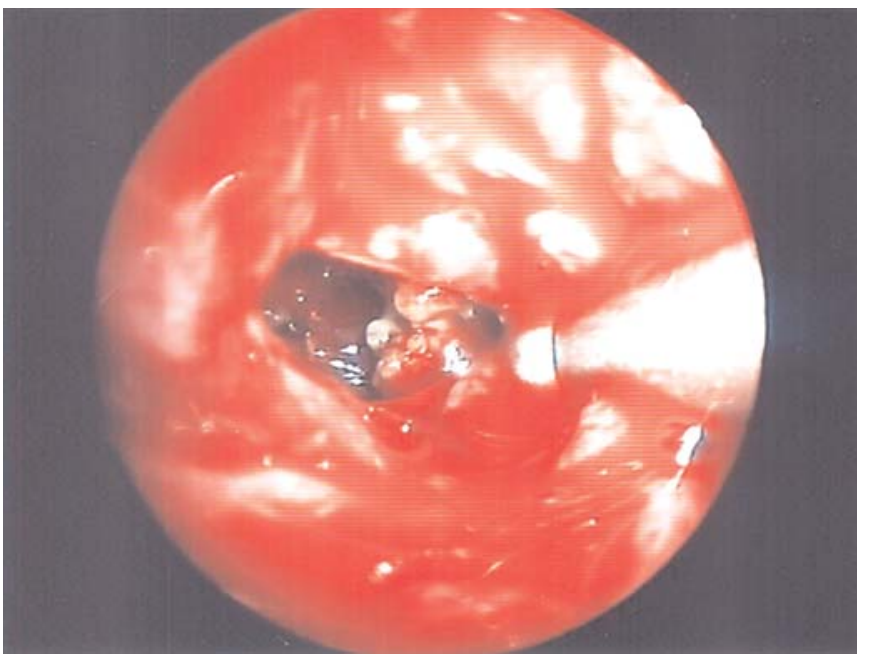

Fig. 2. Fungus ball in the right maxillary sinus (Case \#2). 


\section{Discussion}

Most frequently encountered etiological pathogens of fungus ball disease are Aspergillus fumigatus and Aspergillus flavus, followed by Pseudallescheria boydii, Alternaria and other Dematiaceous species. ${ }^{[6]}$ Previously, the terms aspergilloma, sinus aspergillosis and mycetoma were used to name this disease; however, nowadays the term 'fungus ball' has been used more frequently. Fungus balls are usually seen in elder patients aged 60-70 years and they are frequently encountered in women. ${ }^{[7]}$ The presenting symptoms of the patients are non-specific and mimic chronic bacterial sinusitis. In the present study, the most frequently seen symptoms were postnasal discharge and maxillary pain. The diagnostic criteria for fungus balls defined by deShazo et al. are also important for the discrimination among other types of fungal sinusitis. ${ }^{[8]}$ Our cases were analyzed in consixderation of these criteria.In our study as etiological agents of fungus ball, Aspergillus fumigatus and Dematiceaus sp. were identified. Mean age (64.5 years) and mostly female gender of our patients were in accordance with the literature findings.

One of the important features of fungus balls is that they generally affect only one sinus. In various studies, involvement of mostly maxillary sinus (94\%) followed by sphenoid sinus (4-8\%) was detected. ${ }^{[7]}$ In this study, most frequently $(77.7 \%)$ maxillary sinus disease was found, however fungus balls were increasingly $(22.3 \%)$ detected in sphenoid sinus. Since limited number of patients were included in this study, larger- scale studies might reveal the incidence of fungus balls more precisely.
Presence of diabetes mellitus, long-term use of systemic steroids and antibiotics, radiotherapy and chemotherapy, compromised immune system or use of immunosuppressive drugs increasingly predispose paranasal sinuses to fungal infections. ${ }^{[9]}$ Rarely, association of fungus balls with other diseases (diabetes mellitus, Wegener's granulomatosis, asthma, lenfoproliferative disease etc.) has been reported. This concomitancy was accepted as an incidental finding. ${ }^{[10]}$ In a study, concurrence of fungus balls and diabetes was reported in $4 \%$ of the patients. ${ }^{[10]}$ In the present study, diseases (including diabetes, tuberculosis, chronic renal failure and hepatitis B infection), which might adversely effect immune system of the patients, were detected in five (55.5\%) patients. Diabetes was found in three $(33.3 \%)$ patients. Higher rates of concomitancy of fungus balls with another disease in our study suggest that this concurrence might not be coincidental contrary to the literature findings.

In fungus ball cultures, fungal growth is not frequently observed. Fungal growth is encountered in only 24$50 \%$ of the cultures. ${ }^{[1]}$ In our study, fungal growth was detected in only three $(42.85 \%)$ out of seven samples sent for culture. Our rate is still consistent with the rate reported in the literature. In a publication, the authors identified isolates of aspergillus fumigatus in $93 \%$ of the cultures with fungal growth. ${ }^{[7]}$ In our study, this fungal isolate was detected in $66.6 \%$ of the cultures and Dematiaceous sp. was isolated in the culture of only one patient $(33.3 \%)$. As can be understood from this study, it should be kept in mind that not only Aspergillus sp. causes fungus ball infections. Therefore, despite lower probability of growth in fungal

Table 1. Characteristics of the patients.

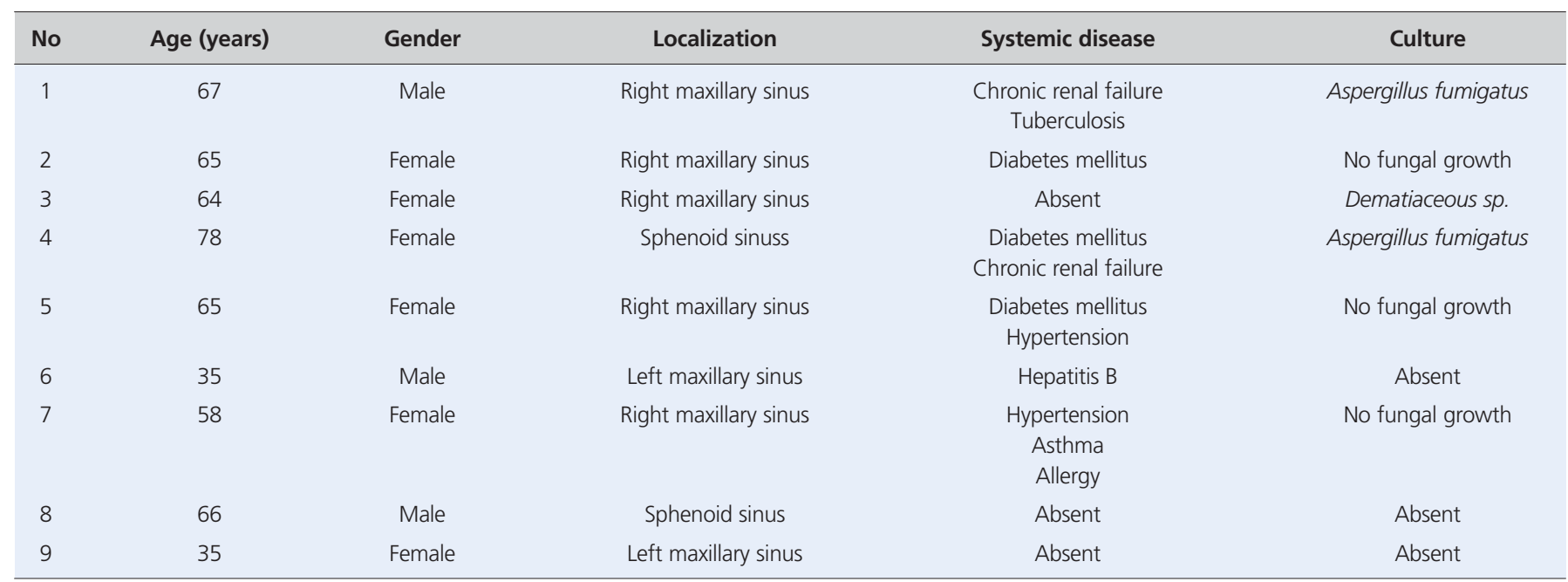


cultures, samples of all patients should be sent for fungal cultures.

Treatment of fungus ball is surgery. If sinus is completely evacuated by surgical means, recurrence is not observed. In our cases, we endoscopically enlarged ostium of the affected sinus and all intrasinusal fungal debris was cleared away. Besides, remnants left in the sinus were eliminated by pressurized irrigation of the sinuses using physiological saline

\section{Conclusion}

In conclusion, nine patients with fungus ball rhinosinusitis were examined. In all patients, the diagnosis of fungus ball rhinosinusitis was confirmed by clinical, radiological and histopathological examinations, and the verification of the disease required additional microbiological analyses in some patients. In $55.5 \%$ of the patients, a concomitant systemic disease such as chronic renal failure, diabetes, tuberculosis, hepatitis infection was detected. As a consequence of this finding, in cases presenting with a systemic disease associated with non-specific symptoms of sinusitis, the presence of a fungus ball should be considered.

Conflict of Interest: No conflicts declared.

\section{References}

1. Grigoriu D, Bambule J, Delacrétaz J, Savary M. Fungal maxillary sinusitis. [Article in French] Dermatologica 1979;159(Suppl 1):180-6.

2. Laskownicka Z, Kurdzielewicz J, Macura A, Okrasifska-Cholewa B. Mycotic sinusitis in children. Mykosen 1978;21:407-11.

3. Dhong HJ, Lanza DC. Fungal rhinosinusitis. In: Kennedy DW, Bolger WE, Zinreich SJ, editors. Diseases of the sinuses: diagnosis and management. Hamilton: BC Decker Inc.; 2001. p. 179-195.

4. Schubert MS. Fungal rhinosinusitis: diagnosis and therapy. Curr Allergy Asthma Rep 2001;1:268-76.

5. Gungor A, Adusumilli V, Corey JP. Fungal sinusitis: progression of disease in immunosuppression--a case report. Ear Nose Throat J 1998;77:207-210.

6. Kantarcıoğlu AS, Yücel A. Mantarların rinosinüzitlerdeki rolü: epidemiyoloji, mikoloji, immünoloji patogenez, sınıflama kriterleri, laboratuar tanımı, antifungallerin tedavideki yeri. Cerrahpaşa Tip Dergisi 2006;37:137-54.

7. Klossek JM, Serrano E, Péloquin L, Percodani J, Fontanel JP, Pessey JJ. Functional endoscopic sinus surgery and 109 mycetomas of the paranasal sinuses. Laryngoscope 1997;107:112-7.

8. deShazo RD, O'Brien M, Chapin K, et al. Criteria for the diagnosis of sinus mycetoma. J Allergy Clin Immunol 1997;99:475-85.

9. De Foer C, Fossion E, Vaillant JMJ. Sinus aspergillosis. Craniomaxillofac Surg 1990;18:33-40.

10. Barry B, Topeza M, Géhanno P. Aspergillosis of the paranasal sinus and environmental factors. [Article in French] Ann Otolaryngol Chir Cervicofac 2002;119:170-3.

11. Ferguson BJ. Fungus balls of the paranasal sinuses. Otolaryngol Clin North Am 2000;33:389-98.

This is an open access article distributed under the terms of the Creative Commons Attribution-NonCommercial-NoDerivs 3.0 Unported (CC BYNC-ND3.0) Licence (http://creativecommons.org/licenses/by-nc-nd/3.0/) which permits unrestricted noncommercial use, distribution, and reproduction in any medium, provided the original work is properly cited.

Please cite this article as: Erkan AN, Köycü A. Our approach to cases with fungus balls of the paranasal sinuses. J Med Updates 2014;4(1):25-28. 